\title{
A novel WDR62 missense mutation in microcephaly with abnormal cortical architecture and review of the literature
}

\author{
Melinda Zombor ${ }^{1} \cdot$ Tibor Kalmár $^{1} \cdot$ Nikoletta Nagy $^{2} \cdot$ Marianne Berényi $^{3} \cdot$ Borbála Telcs $^{3} \cdot$ Zoltán Maróti $^{1}$. \\ Oliver Brandau ${ }^{4} \cdot$ László Sztriha $^{1}$ [D
}

Received: 27 May 2018 / Revised: 5 January 2019 / Accepted: 17 January 2019 / Published online: 1 February 2019

(C) Institute of Plant Genetics, Polish Academy of Sciences, Poznan 2019

\begin{abstract}
Autosomal recessive primary microcephaly $(\mathrm{MCPH})$ is a group of rare neurodevelopmental diseases with severe microcephaly at birth. One type of the disorder, MCPH2, is caused by biallelic mutations in the WDR62 gene, which encodes the WD repeatcontaining protein 62. Patients with WDR62 mutation may have a wide range of malformations of cortical development in addition to congenital microcephaly. We describe two patients, a boy and a girl, with severe congenital microcephaly, global developmental delay, epilepsy, and failure to thrive. MRI showed hemispherical asymmetry, diffuse pachygyria, thick gray matter, indistinct gray-white matter junction, and corpus callosum and white matter hypoplasia. Whole exome sequencing revealed the same novel homozygous missense mutation, c.668T>C, p.Phe223Ser in exon 6 of the WDR62 gene. The healthy parents were heterozygous for this mutation. The mutation affects a highly conserved region in one of the WD repeats of the WDR62 protein. Haplotype analysis showed genetic relatedness between the families of the patients. Our findings expand the spectrum of mutations randomly distributed in the WDR62 gene. A review is also provided of the brain malformations described in WDR62 mutations in association with congenital microcephaly.
\end{abstract}

Keywords Microcephaly · Malformations of cortical development · Whole exome sequencing · WDR62 mutation · Global developmental delay

\section{Introduction}

Microcephaly is defined as an occipitofrontal head circumference below the third percentile or more than two standard deviations (SD) below the mean for sex, age, and ethnicity. It can be associated with delayed motor and cognitive

Communicated by: Michal Witt development, various neurological signs, intellectual disability, epilepsy, and autism and accounts for a significant proportion of neurodevelopmental disorders in childhood. Microcephaly may develop prenatally or postnatally and may have genetic or non-genetic cause. Any condition that affects important processes of brain growth, including

Zoltán Maróti

maroti.zoltan@med.u-szeged.hu

Oliver Brandau

oliver.brandau@bioscientia.de

1 Department of Pediatrics, University of Szeged, Temesvári krt. 35-37, Szeged 6726, Hungary

2 Department of Medical Genetics, University of Szeged, Szeged, Hungary

3 Department of Developmental Neurology, St. Margaret Hospital, Budapest, Hungary

4 Centogene AG, Rostock, Germany 
progenitor cell proliferation, cell differentiation, and cell death, can lead to microcephaly (Alcantara and O'Driscoll 2014; Barbelanne and Tsang 2014; Zaqout et al. 2017). Anomalies causing microcephaly may exclusively affect cerebral development (non-syndromic microcephaly) or may be associated with dysmorphic features and extracerebral malformations (syndromic microcephaly). The spectrum of phenotypes and associated disorders of "microcephaly" is wide with more than 1300 entries recorded to April 2018 in The Online Mendelian Inheritance in Man (OMIM) database.

Although a wide spectrum of genetic defects can result in microcephaly, traditionally, a group of microcephalies is distinguished as autosomal recessive primary microcephaly (MicroCephaly Primary Hereditary, MCPH) (Barbelanne and Tsang 2014; Zaqout et al. 2017). At least 17 genetic loci (MCPH1-17) have been implicated in $\mathrm{MCPH}$, all of which have now been connected to single genes: $M C P H 1$, WDR62, CDK5RAP2, KNL1, ASPM, CENPJ, STIL, CEP135, CEP152, ZNF335, PHC1, CDK6 and CENPE, SASS6, MFSD2A, ANKLE2, CIT (Zaqout et al. 2017). Many of the proteins encoded by these genes interact with the centrosome, which organizes the separation of chromosome copies during cell division (Alcantara and O'Driscoll 2014; Barbelanne and Tsang 2014; Zaqout et al. 2017).

Mutations in WDR62, encoding WD repeat-containing protein 62, are responsible for $\mathrm{MCPH} 2$, which is the second most frequent form of MCPH after MCPH5 caused by ASPM mutations. Over 40 pathogenic mutations in WDR62 have already been published. In addition to microcephaly, a wide range of cortical malformations was also described in these patients (Bacino et al. 2012; Banerjee et al. 2016; Bastaki et al. 2016; Bhat et al. 2011; Farag et al. 2013; Sajid Hussain et al. 2013; Kousar et al. 2011; McDonell et al. 2014; Memon et al. 2013; Miyamoto et al. 2017; Murdock et al. 2011; Najmabadi et al. 2011; Nardello et al. 2018; Naseer et al. 2017; Poulton et al. 2014; Rupp et al. 2014; Wang et al. 2017).

We report on two patients, a boy and a girl with the same novel missense mutation in WDR62, revealed by whole exome sequencing. Both of them have pachygyria and thick cortex in addition to severe congenital microcephaly, short stature, epilepsy, and severe developmental delay.

\section{Clinical report}

\section{Patient 1}

This 5-year-old boy was born at term from the third pregnancy with Cesarean section to a 32-year-old mother and 37-year-old father. The parents are consanguineous of Romani ethnicity (Fig. 1a). Apgar scores were 8 and 8 at 1 and 5 min, respectively. Severe microcephaly was noted at birth with head circumference of $30 \mathrm{~cm}(-3.5 \mathrm{SD})$. The birthweight was $2900 \mathrm{~g}$
(-1SD) and length $50 \mathrm{~cm}(0.1 \mathrm{SD})$. The pregnancy was unremarkable, with no report of infection, alcohol use, or substance abuse. The parents had unremarkable medical histories, normal head size and normal intellect. They have a healthy son and a healthy daughter. Microcephaly progressed, with head circumference of $40 \mathrm{~cm}(-6 \mathrm{SD})$ at 2 years and $41.5 \mathrm{~cm}(-6 \mathrm{SD})$ at 4 years of age. The patient also had short stature, with a height of $89 \mathrm{~cm}(-3.4 \mathrm{SD})$ and a weight of $12 \mathrm{~kg}(-2.4 \mathrm{SD})$ at 4 years of age. Sloping forehead and disproportionately large face and ears as compared to the skull were observed. He followed objects and responded to loud sounds. Global hypotonia was present with preserved deep tendon reflexes. Motor and intellectual development was severely impaired with inability to sit and stand unsupported, or reach out for objects at the age of 5 years. He had no words, but showed emotions. Infantile spasms began at 4 months of age and were well controlled by vigabatrin, which was tapered off and discontinued by 3 years of age. One year later, complex partial seizures appeared and the EEG showed interictal short paroxysms of bilateral spike and wave discharges. Valproate treatment was initiated and proved to be successful. Metabolic screening (plasma amino acids and urine organic acids) was negative.

MRI at age of 5 months showed hemispherical asymmetry $(\mathrm{R}>\mathrm{L})$ and abnormal cortical pattern. Diffuse pachygyria was observed with a few broad gyri, thick gray matter, and shallow sulci. The gray-white matter junction appeared indistinct at some areas. Moderate hypoplasia of the corpus callosum was seen. The white matter was thin in association with an asymmetrical $(\mathrm{L}>\mathrm{R})$ dilatation of the lateral ventricles. The myelination of the corpus callosum and internal capsule was appropriate for the infant's age. Moderate cerebellar hypoplasia was also seen. The Virchow-Robin spaces were dilated. The basal ganglia, brainstem, and hippocampus were preserved (Fig. 2a, b).

\section{Patient 2}

This 4-year-old girl was born at term from the first pregnancy with Cesarean section because of fetal bradycardia to a 17-year-old mother and 20-year-old father. The parents are of Romani ethnicity; they deny consanguinity (Fig. 1b). Apgar scores were 7, 9, and 10 at 1, 5, and $10 \mathrm{~min}$, respectively. The pregnancy was complicated with urinary tract infection. Severe microcephaly was noted at birth with head circumference of $28 \mathrm{~cm}$ (5SD). Her birthweight was $2490 \mathrm{~g}(-0.4 \mathrm{SD})$ and length $46 \mathrm{~cm}(-1.7 \mathrm{SD})$. There was no evidence of inborn error of metabolism, intrauterine infection, alcohol use, or substance abuse. The parents had unremarkable medical histories, normal head size and normal intellect. Microcephaly progressed, with head circumference of $39 \mathrm{~cm}(-5.9 \mathrm{SD})$ at 2 years and $40 \mathrm{~cm}(-6.6 \mathrm{SD})$ at 


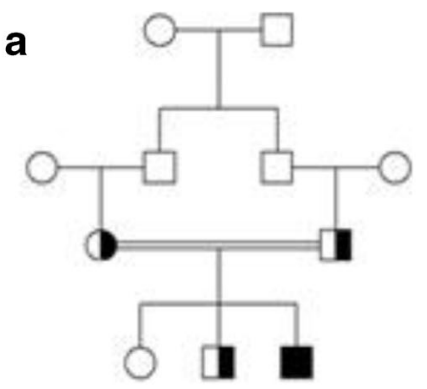

b

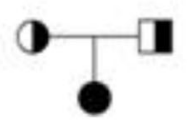

\section{Wild type}

(Deterozygous carrier of the mutation

Homozygous mutant

C
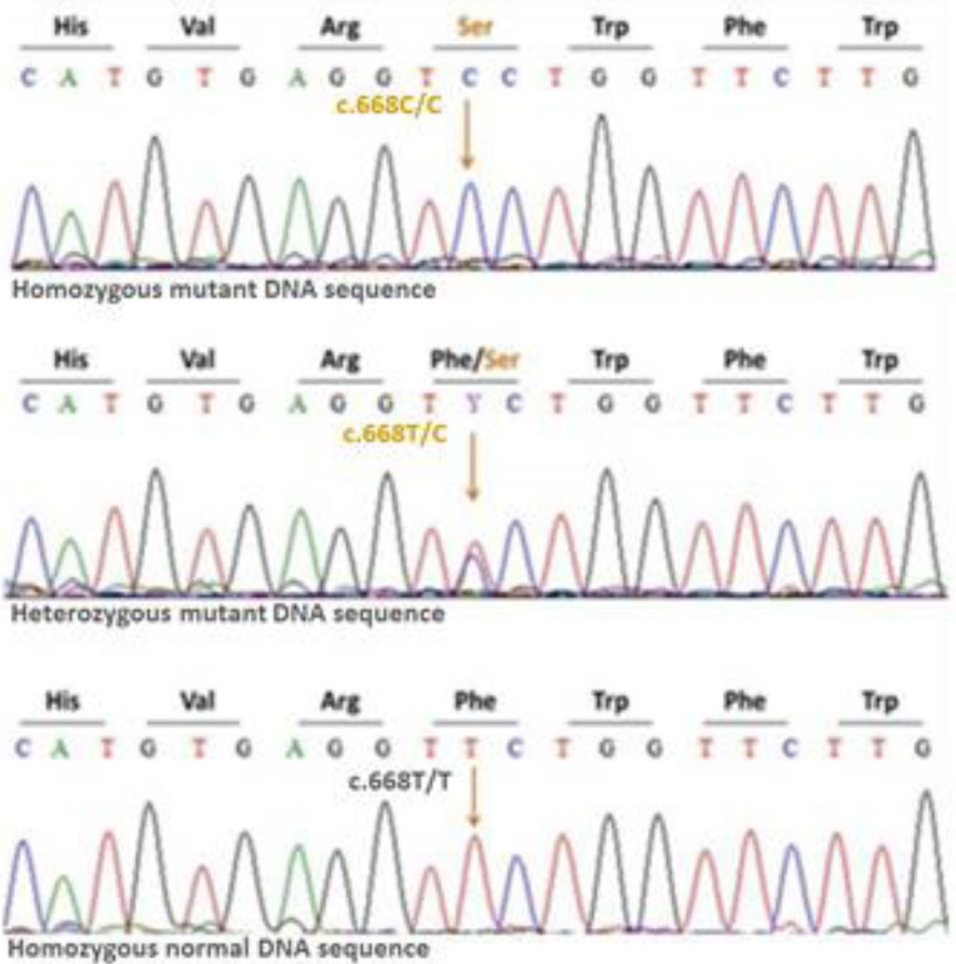

d

Homozygous normal DNA sequence

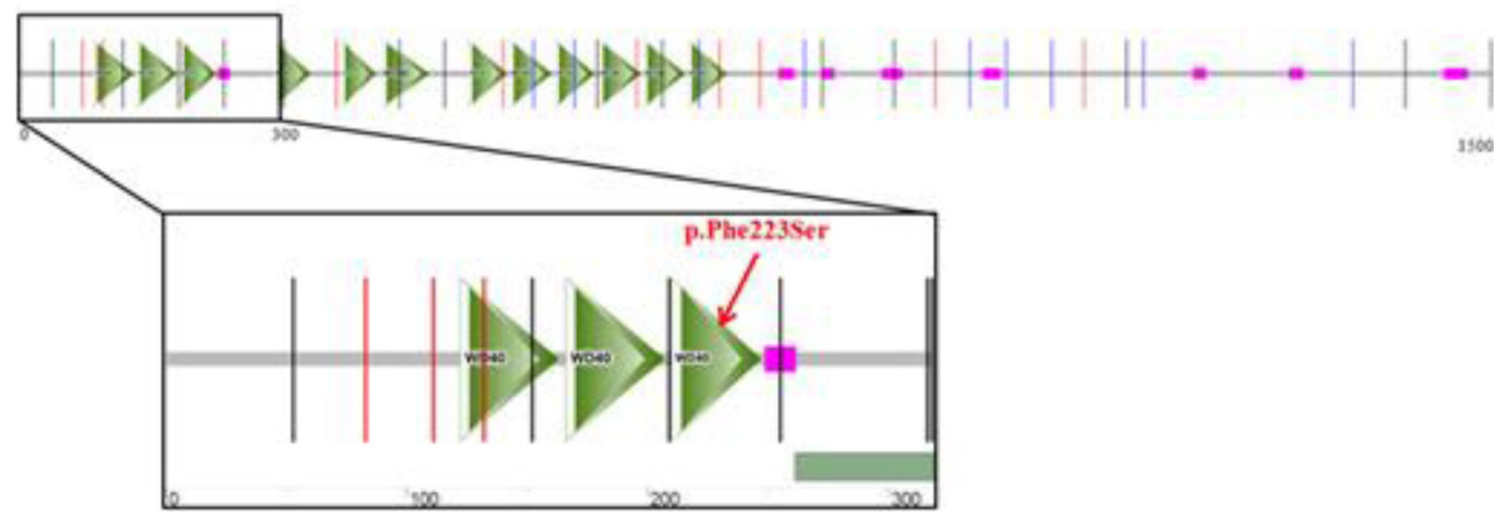

Fig. 1 Pedigree of patient 1 (a) and patient 2 (b). Sanger sequencing of part of exon 6 of the WDR62 gene shows the homozygous T to C mutation at position 668 of the coding DNA sequence in the patients. The 668 positions of the coding DNA sequences are indicated by arrows. The

4 years of age. The patient also had short stature, with height of $88 \mathrm{~cm}(-3.4 \mathrm{SD})$ and weight of $12.4 \mathrm{~kg}(-$ mutation was heterozygous in the parents and brother of patient $1(\mathrm{Y}=$ $\mathrm{T} / \mathrm{C}$ ). A normal sequence is also shown in an unrelated control subject (c). The mutation affects one of the WD40 repeats in the WDR62 protein (d)

2.0SD) at 4 years of age. On examination at the age of 14 months, she had severe convergent squint, but 
Fig. 2 MRI of patient $1(a, b)$ at the age of 5 months and patient 2 $(\mathrm{c}, \mathrm{d})$ at the age of 4 years. The T2-weighted axial images demonstrate hemispherical asymmetry, diffuse pachygyria with a few broad gyri and shallow sulci, wide gray matter, and indistinct whitegray matter border in certain areas. The white matter is thin and the ventricles are asymmetrically enlarged. The Virchow spaces are dilated

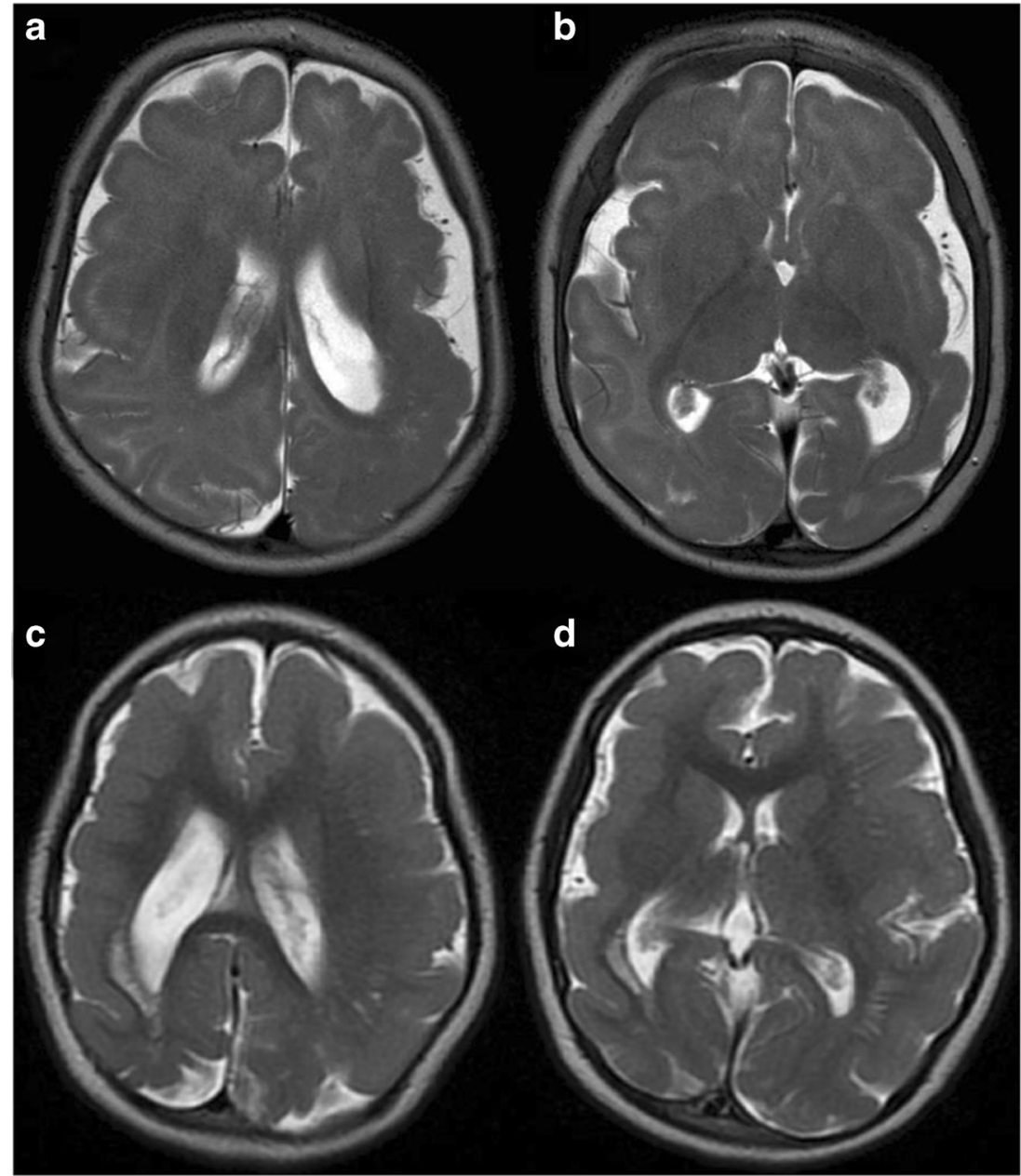

followed objects and responded to loud sounds. Her motor and cognitive development was severely delayed with inability to sit, stand, or reach out for objects. There was a moderate decrease in the muscle tone with slight leftsided weakness and preserved deep tendon reflexes. No further development was observed until the last followup at 4 years of age. Complex partial seizures started after 3 years of age, and the interictal EEG showed bilateral spike and wave discharges. The epilepsy was controlled with valproate treatment.

MRI at the age of 4 years showed hemispherical asymmetry $(\mathrm{L}>\mathrm{R})$ and abnormal cortical pattern similar to patient 1 . Diffuse pachygyria, thick gray matter, and shallow sulci were observed. The white matter was thin with more or less age-appropriate myelin formation. The lateral ventricles were dilated in an asymmetrical $(\mathrm{R}>\mathrm{L})$ manner. On T2 images, a narrow periventricular band with high signal intensity was observed adjacent to the occipital horn of the right lateral ventricle. The VirchowRobin spaces were dilated. The corpus callosum, basal ganglia, hippocampi, brainstem, and cerebellum were preserved (Fig. 2C, D).
The family members of the two patients were unaware of any relatedness.

\section{Molecular analysis}

Routine chromosomal analysis by G-banding showed normal karyotype in both patients. DNA was isolated from the peripheral blood. Array comparative genomic hybridization using the Agilent $180 \mathrm{~K}$ oligo-array showed normal genomic copy number in both patients.

Whole exome sequencing (WES) of affected probands and unaffected parents was performed with CentoXome ${ }^{\circledR}$ at Centogene AG (Rostock, Germany). Genomic capture was carried out with Illumina's Nextera Rapid Capture Exome Kit. Massively parallel sequencing was done using NextSeq500 Sequencer (Illumina) in combination with the NextSeq ${ }^{\text {TM }} 500$ High Output Kit $(2 \times 150$ bp). Raw sequence data analyses, including base calling, de-multiplexing, alignment to the hg19 human reference genome (Genome Reference Consortium GRCh37), and variant calling, were performed using an in-house bioinformatics pipeline. For variant filtration, all disease-causing variants reported in 
HGMD®, ClinVar, or in CentoMD® as well as all variants with minor allele frequency (MAF) of less than $1 \%$ in ExAc database were considered. Variants that possibly impair the protein sequence, i.e., disruption of conserved splice sites, missense, nonsense, read-throughs, or small insertions/deletions, were prioritized. All relevant inheritance patterns were considered. All candidate pathogenic variants not previously identified were confirmed by conventional PCR amplification and Sanger sequencing. Segregation of these changes with the disease was assessed for all available family members.

We identified the same homozygous variant, c.668T $>C$, p.Phe $223 \mathrm{Ser}$ in exon 6 in the WDR62 gene (NM_001083961.1) in both patients. The detected variant was also found in heterozygous state in the patients' parents and the brother of patient 1 , whereas it was absent in his sister (Fig. 1a, b, c). To date, this variant has not been described in the Exome Aggregation Consortium, Exome Sequencing Project, or the 1000 Genome Browser. This variant is located in a highly conserved nucleotide (phyloP, 4.48) with large physicochemical differences between the exchanged amino acids phenylalanine and serine (Alamut v.2.7.1). Prediction programs Polyphen2, SIFT, and MutationTaster predicted pathogenicity of the missense variant which affects the WD40 repeat region of the protein (Fig. 1d).

\section{Haplotype analysis of the families}

Since the two families were unaware of any relation between them, we performed a haplotype analysis to investigate their potential genetic relation. Plink (version v1.90b4.9) was used to convert variants in the region of interest to PED and MAP files from the joint VCF file (Chang et al. 2015). Haplotype analysis was performed by Merlin (version 1.1.2.) software with the "-best" option using the PED, DAT, and MAP files prepared manually from the plink output files (Abecasis et al. 2002). HaploPainter (version 1.043) was used to visualize the haplotypes in the families (Thiele and Nürnberg 2005). Our analysis showed that both families carry exactly the same haplotype for the entire WDR62 gene (around 55 kilobases) as shown in Fig. 3. Our results suggest that the two families are closely related genetically.

\section{Discussion}

The human WDR62 gene maps to chromosome 19q13.12, consists of 32 exons, and encodes a 1523 amino acid protein containing several WD40 repeats (Bilgüvar et al. 2010; Nicholas et al. 2010; Yu et al. 2010). We found the same novel missense mutation in the WDR62 gene in two patients from related families with microcephaly in association with diffuse pachygyria, thickened cortex, and indistinct gray-white matter junction. Wide spectrum of cortical malformations has been reported in WDR62 mutations. Apart from pachygyria, thickened cortex and indistinct gray-white matter junction, band heterotopia, polymicrogyria, schizencephaly, and asymmetry of hemispheres have also been observed (Tables 1 and 2). Neuropathology in a fetus with WDR62 mutation revealed severe disruption of cortical neuronal architecture, immature radial columnar organization, and heterotopia in the intermediate zone (Yu et al. 2010).

The frameshifts, missense, nonsense, and splice site mutations in the WDR62 gene are randomly distributed (Tables 1 and 2). It has been suggested initially that missense mutations may cause a deficiency of neurogenesis resulting in primary microcephaly, but nonsense mutations may cause a more severe microcephaly phenotype with addition of a cerebral cortex lamination defect (Nicholas et al. 2010). Later studies, however, did not recognize any genotype-phenotype correlation. The novel missense mutation c.668T >C, p.Phe223Ser in our patients is associated with severe defects in cortical architecture. It affects one of the WD40 repeat regions of the WDR62 protein. WD40 repeat is a short structural motif of approximately 40 amino acids, often terminating in a tryptophan-aspartic acid (W-D) dipeptide. The common function of all WD40 repeat proteins is coordinating multiprotein complex assemblies, where the repeating units serve as a rigid scaffold for protein interactions (Li and Roberts 2001).

Central to the mitotic process is the formation and maintenance of a microtubule-based spindle apparatus organized by the centrosomes (Prosser and Pelletier 2017). The centrosome contains a pair of cylindrical centrioles in an orthogonal configuration and each made primarily of nine microtubule triplets. The centrioles are surrounded by pericentriolar matrix of proteins and centrosomal satellites. The satellites are granular structures implicated in the trafficking of material involved in centriole assembly (Bettencourt-Dias et al. 2011). It is noteworthy that the two centrioles differ in their structure and function. The older, "mother" centriole possesses subdistal appendages, where microtubules are docked, and distal appendages, which are important for docking to the plasma membrane. In contrast, the younger "daughter" centriole, which is formed during the preceding $\mathrm{S}$ phase, lacks these structures (Bettencourt-Dias et al. 2011). Full acquisition of appendages by the daughter centriole is not achieved until at least one-and-a half cell cycles later. Centrosome replication during each cell cycle leads to asymmetric centrosome inheritance, that is, the formation of two centrosomes: one of which retains the original old mother centriole (that is, the "mother" centrosome) while the other receives the new "mother" centriole (that is, the daughter centrosome). Asymmetric centrosome inheritance maintains neural progenitors in the neocortex (Wang et al. 2009).

At the onset of mitosis, centrosomes separate and the pericentriolar matrix expands through the coordinated activation and recruitment of spindle pole proteins (Fujita et al. 
Fig. 3 Haplotype analysis of the two families (a family $1, \mathrm{~b}$ family 2). Except the 19:36558314T >c unique variant, all the other examined SNPs are listed by their reference numbers. The identical haplotypes are colored matched. The haplotype linked with the causative mutation is colored magenta a

rs11538454
rs12608517
19:36558314T>C
rs10423651
rs766195936
rs11669890
rs7246292
rs45567532
rs2301734
rs4806263
rs3746271
rs2301736
rs61494900
rs2301737
rs2285745
rs2311004
rs17851502
rs2074435
rs1008328

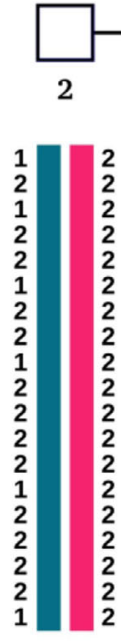

b

rs11538454
rs12608517
$19: 36558314 T>C$
rs10423651
rs766195936
rs11669890
rs7246292
rs45567532
rs2301734
rs4806263
rs3746271
rs2301736
rs61494900
rs2301737
rs2285745
rs2311004
rs17851502
rs2074435
rs1008328

rs1008328

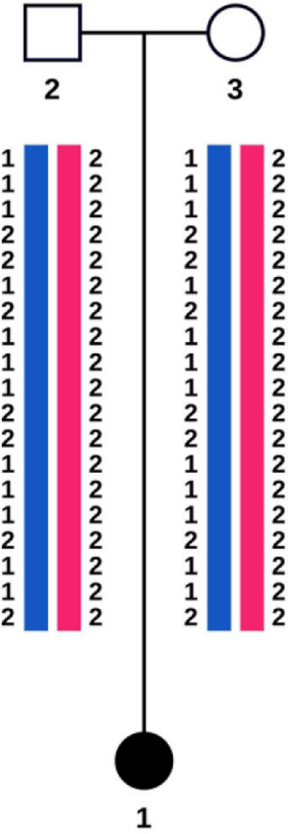

\begin{tabular}{l|l}
2 & 2 \\
2 \\
2 \\
2 \\
2 \\
2 \\
2 \\
2 \\
2 \\
2 \\
2 \\
2 \\
2 \\
2 \\
2 \\
2 \\
2 \\
2 \\
2 \\
2 \\
2 \\
2 \\
2 \\
2 \\
2 \\
2 \\
2
\end{tabular}

rs11538454
rs12608517
$19: 36558314 T>C$
rs10423651
rs766195936
rs11669890
rs7246292
rs45567532
rs2301734
rs4806263
rs3746271
rs2301736
rs61494900
rs2301737
rs2285745
rs2311004
rs17851502
rs2074435
rs1008328

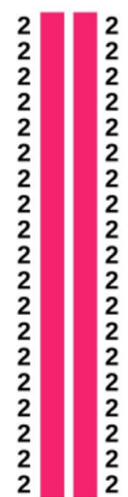

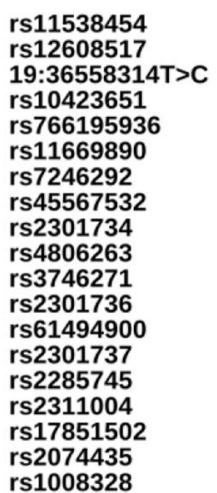

2016). Centrosomal duplication results in the generation of a bipolar mitotic spindle. The mitotic spindle is an array of microtubules, which are assembled from dimers of $\alpha$ - and $\beta$-tubulins, initiated by a $\gamma$-tubulin ring complex. The chromosomes attach to bundles of microtubules via kinetochores, which are multiprotein complexes that assemble on the centromere of each sister chromatid (Prosser and Pelletier 2017). A coordinated interplay between proteins, including WDR62, i.e., a large network of protein-protein interactions, is essential for normal centrosomal function. It has been demonstrated recently that four of the primary microcephaly-associated proteins, such as CDK5RAP2, CEP152, WDR62, and CEP63, assemble in a step-wise hierarchical manner. Both the microcephaly-associated proteins and their centriolar satellite partner proteins are required for the centrosomal localization of CDK2, a cyclin-dependent kinase, which has a role in both centriole duplication and cell cycle progression (Kodani et al. 2015; Meraldi et al. 1999). Loss of any of the microcephalyassociated proteins, like loss of functioning WDR62 in our patients, disrupts centriole duplication or stability (Fujita et al. 2016; Kodani et al. 2015; Meraldi et al. 1999). The regulation and subcellular localization of WDR62 is cell cycle dependent. Studies by immunocytochemistry revealed that WDR62 protein showed cytosolic distribution in the interphase but it accumulated strongly at the spindle poles during mitosis (Bogoyevitch et al. 2012; Farag et al. 2013; Nicholas et al. 2010; Sgourdou et al. 2017; Yu et al. 2010). Fibroblasts from patient with homozygous WDR62 mutation or cells transfected with missense and frameshift mutations in WDR62 failed to show protein expression at the spindle poles (Farag et al. 2013; Nicholas et al. 2010; Sgourdou et al. 2017). WDR62 recruitment coincides with increased activity of Aurora A kinase, a centrosomal and spindle-associated protein that regulates spindle architecture and stability during mitosis (Carmena et al. 2009). It potentiates the recruitment of WDR62 to the spindle pole and is essential for mitotic spindle regulation (Lim et al. 2016).

The mitotic processes are dependent also upon the highly conserved chromosomal passenger complex, consisting of Aurora B kinase, inner centromere protein (INCENP), 
Table 1 Homozygous WDR62 mutations and associated brain malformation patterns

\begin{tabular}{|c|c|c|c|c|c|}
\hline Location & Nucleotide variation & Amino acid variation & Mutation type & $\begin{array}{l}\text { Brain malformations (MRI findings) in addition to } \\
\text { microcephaly }\end{array}$ & References \\
\hline Exon 2 & c. $193 \mathrm{G}>\mathrm{A}$ & p.Val65Met & Missense & $\begin{array}{l}\text { Simplified gyral pattern, polymicrogyria, } \\
\text { schizencephaly, dysmorphic corpus callosum }\end{array}$ & $\begin{array}{l}\text { Nicholas } \\
\text { et al. } \\
(2010) \\
\text { Yu et al. } \\
\text { (2010) }\end{array}$ \\
\hline Exon 3 & c. $332 \mathrm{G}>\mathrm{C}$ & p.Arg111Thr & Missense/splice-site & Not reported & $\begin{array}{l}\text { Sajid } \\
\text { Hussain } \\
\text { et al. } \\
\text { (2013) }\end{array}$ \\
\hline Exon 4 & c.363delT & p.Asp112MetfsX5 & Frameshift & $\begin{array}{l}\text { Simplified gyral pattern, hemispherical asymmetry, } \\
\text { suggestion of subcortical heterotopia, thin corpus } \\
\text { callosum, enlarged lateral ventricles }\end{array}$ & $\begin{array}{l}\text { Yu et al. } \\
\quad(2010)\end{array}$ \\
\hline Exon 4 & c. $390 \mathrm{G}>\mathrm{A}$ & p.Glu130Glu & Splice-site & Agyria-pachygyria & $\begin{array}{l}\text { Bastaki } \\
\text { et al. } \\
\text { (2016) }\end{array}$ \\
\hline Exon 5 & c.535_536insA & p.Met179fsX21 & Frameshift & Pachygyria, cortical dysplasia & $\begin{array}{c}\text { Bhat et al. } \\
\text { (2011) }\end{array}$ \\
\hline Exon 6 & c. $668 \mathrm{~T}>\mathrm{C}$ & p.Phe223Ser & Missense & $\begin{array}{l}\text { Diffuse pachygyria, thickened cortex, abnormal corpus } \\
\text { callosum }\end{array}$ & This study \\
\hline Exon 6 & c. $671 \mathrm{G}>\mathrm{C}$ & p.Trp224Ser & Missense & $\begin{array}{l}\text { Pachygyria, polymicrogyria, cortical thickening, } \\
\text { under-opercularization, schizencephaly, dysmorphic } \\
\text { hippocampus, corpus callosum hypoplasia }\end{array}$ & $\begin{array}{l}\text { Bilgüvar } \\
\text { et al. } \\
\text { (2010) }\end{array}$ \\
\hline $\begin{array}{l}\text { Exon } \\
8-9\end{array}$ & $\begin{array}{l}\text { c. } 883-1273- \\
1237-850 \mathrm{del}\end{array}$ & Deletion of exon $8-9$ & Micro deletion & Not reported & $\begin{array}{l}\text { Wang et al. } \\
\quad(2017)\end{array}$ \\
\hline Exon 8 & c. $900 \mathrm{C}>\mathrm{A}$ & p.Cys300X & Nonsense & Pachygyria, polymicrogyria, band heterotopia & $\begin{array}{c}\text { Bhat et al. } \\
\text { (2011) }\end{array}$ \\
\hline Intron 8 & c. $1043+1 \mathrm{G}>\mathrm{A}$ & p.Ser348ArgfsX63 & Splice-site & $\begin{array}{l}\text { Diminished sulcation, band heterotopia, thin corpus } \\
\text { callosum }\end{array}$ & $\begin{array}{l}\text { Yu et al. } \\
\quad(2010)\end{array}$ \\
\hline Exon 9 & c.1143delA & p.His381Profs X48 & Frameshift & $\begin{array}{l}\text { Brain atrophy, schizencephaly, corpus callosum } \\
\text { hypoplasia (CT only) }\end{array}$ & $\begin{array}{l}\text { Memon } \\
\text { et al. } \\
\text { (2013) }\end{array}$ \\
\hline Exon 9 & c. $1194 \mathrm{G}>\mathrm{A}$ & p.Trp398X & Nonsense & Not reported & $\begin{array}{l}\text { Sajid } \\
\text { Hussain } \\
\text { et al. } \\
\text { (2013) }\end{array}$ \\
\hline Exon 9 & c. $1198 \mathrm{G}>\mathrm{A}$ & p.Glu400Lys & Missense & Pachygyria (CT only) & $\begin{array}{l}\text { Bacino } \\
\text { et al. } \\
\text { (2012) }\end{array}$ \\
\hline Exon 10 & c. $1313 \mathrm{G}>\mathrm{A}$ & p.Arg 438 His & Missense & $\begin{array}{l}\text { Simplified gyral pattern, normal cortical thickness with } \\
\text { indistinct border }\end{array}$ & $\begin{array}{l}\text { Kousar } \\
\text { et al. } \\
(2011) \\
\text { Nicholas } \\
\text { et al. } \\
(2010) \\
\text { Sajid } \\
\text { Hussain } \\
\text { et al. } \\
\text { (2013) }\end{array}$ \\
\hline Exon 11 & c. $1408 \mathrm{C}>\mathrm{T}$ & p.Gln $470 X$ & Nonsense & $\begin{array}{l}\text { Pachygyria, cortical thickening, } \\
\text { under-opercularization, dysmorphic hippocampus, } \\
\text { corpus callosum hypoplasia }\end{array}$ & $\begin{array}{l}\text { Bilgüvar } \\
\text { et al. } \\
\text { (2010) }\end{array}$ \\
\hline Exon 11 & c. $1531 \mathrm{G}>\mathrm{A}$ & p.Asp511Asn & Missense & Not reported & $\begin{array}{l}\text { Kousar } \\
\quad \text { et al. } \\
\text { (2011) }\end{array}$ \\
\hline
\end{tabular}


Table 1 (continued)

Location Nucleotide variation Amino acid variation Mutation type

Brain malformations (MRI findings) in addition to microcephaly

\begin{tabular}{|c|c|c|c|c|c|}
\hline & & & & & $\begin{array}{l}\text { Nicholas } \\
\text { et al. } \\
\text { (2010) }\end{array}$ \\
\hline Exon 12 & c. $1576 \mathrm{G}>\mathrm{T}$ & p.Glu526X & Nonsense & $\begin{array}{l}\text { Pachygyria, cortical thickening, dysmorphic } \\
\text { hippocampus, corpus callosum hypoplasia }\end{array}$ & $\begin{array}{l}\text { Bilgüvar } \\
\text { et al. } \\
\text { (2010) }\end{array}$ \\
\hline Exon 12 & c. $1576 \mathrm{G}>\mathrm{A}$ & p.Glu526Lys & Missense & $\begin{array}{l}\text { Pachygyria, cortical thickening, } \\
\text { under-opercularization, corpus callosum hypoplasia }\end{array}$ & $\begin{array}{l}\text { Bilgüvar } \\
\text { et al. } \\
\text { (2010) }\end{array}$ \\
\hline Exon 12 & c. $1606 \mathrm{G}>\mathrm{T}$ & p.Glu536X & Nonsense & $\begin{array}{l}\text { Pachygyria, thickened cortex, corpus callosum } \\
\text { dysplasia }\end{array}$ & $\begin{array}{l}\text { Poulton } \\
\text { et al. } \\
\text { (2014) }\end{array}$ \\
\hline Exon 14 & c.1821dupT & p.Arg608SerfsX26 & Frameshift & Details not reported & $\begin{array}{l}\text { McDonell } \\
\text { et al. } \\
\text { (2014) }\end{array}$ \\
\hline Exon 15 & c. $1942 \mathrm{C}>\mathrm{T}$ & p.Gln648X & Nonsense & $\begin{array}{l}\text { Hemispherical asymmetry, ill-defined gyral pattern } \\
\text { (CT) }\end{array}$ & $\begin{array}{l}\text { Kousar } \\
\quad \text { et al. } \\
\quad(2011)\end{array}$ \\
\hline Exon 17 & c. $2115 \mathrm{C}>\mathrm{G}$ & p.Gly705Gly & Splice-site & Cerebellar atrophy, cortical structure not reported & $\begin{array}{l}\text { Najmabadi } \\
\text { et al. } \\
\text { (2011) }\end{array}$ \\
\hline $\begin{array}{c}\text { Intron } \\
21\end{array}$ & c. $2520+5 \mathrm{G}>\mathrm{T}$ & p.Asp823AlafsX5 & Splice-site & Not reported & $\begin{array}{l}\text { Wang et al. } \\
\qquad(2017)\end{array}$ \\
\hline Exon 22 & c.2527dupG & p.Asp843GlyfsX3 & Frameshift & Hemispherical asymmetry, ill-defined gyral pattern & $\begin{array}{l}\text { Rupp et al. } \\
\text { (2014) }\end{array}$ \\
\hline Exon 22 & c. $2588 \mathrm{G}>\mathrm{A}$ & p.Arg863His & Missense & Polymicrogyria, incomplete opercularization & $\begin{array}{l}\text { Poulton } \\
\text { et al. } \\
\text { (2014) }\end{array}$ \\
\hline Exon 22 & c.2667_2668GA $>$ TT & p.Met[889Ile;Lys890X] & Nonsense & Not reported & $\begin{array}{l}\text { Wang et al. } \\
\qquad(2017)\end{array}$ \\
\hline \multirow[t]{2}{*}{ Exon 23} & c.2863delGACA & p.Asp955AlafsX112 & Frameshift & $\begin{array}{l}\text { Pachygyria, thickened cortex, corpus callosum } \\
\text { dysplasia }\end{array}$ & $\begin{array}{l}\text { Poulton } \\
\text { et al. } \\
\text { (2014) }\end{array}$ \\
\hline & & & & & $\begin{array}{l}\text { Sgourdou } \\
\text { et al. } \\
\quad(2017)\end{array}$ \\
\hline $\begin{array}{c}\text { Intron } \\
23\end{array}$ & $\begin{array}{l}\text { c. } 2867+4- \\
\quad \text { c. } 2867+7 \text { delGGT- } \\
\quad \text { G }\end{array}$ & p.Ser956CysfsX38 & Splice-site & $\begin{array}{l}\text { Band heterotopia, thin corpus callosum (Appearance of } \\
\text { the cortex not reported) }\end{array}$ & $\begin{array}{l}\text { Yu et al. } \\
\quad(2010)\end{array}$ \\
\hline Exon 27 & c. $3232 \mathrm{G}>\mathrm{A}$ & p.Ala1078Thr & Missense & Not reported & $\begin{array}{l}\text { Nicholas } \\
\text { et al. } \\
\text { (2010) }\end{array}$ \\
\hline $\begin{array}{c}\text { Intron } \\
27\end{array}$ & c. $3335+1 \mathrm{G}>\mathrm{C}$ & p.? & Splice site & Polymicrogyria, gray-white matter blurring & $\begin{array}{l}\text { Nardello } \\
\quad \text { et al. } \\
\text { (2018) }\end{array}$ \\
\hline Exon 28 & c.3361delG & p.Ala1121GlnfsX6 & Frameshift & Not reported & $\begin{array}{l}\text { Sajid } \\
\text { Hussain } \\
\text { et al. } \\
\text { (2013) }\end{array}$ \\
\hline Exon 29 & c. $3503 \mathrm{G}>\mathrm{A}$ & p.Trp1168X & Nonsense & Not reported & $\begin{array}{l}\text { Sajid } \\
\text { Hussain } \\
\text { et al. } \\
\text { (2013) }\end{array}$ \\
\hline
\end{tabular}

Exon 30

p.Gly1275AlafsX21 Frameshift 
Table 1 (continued)

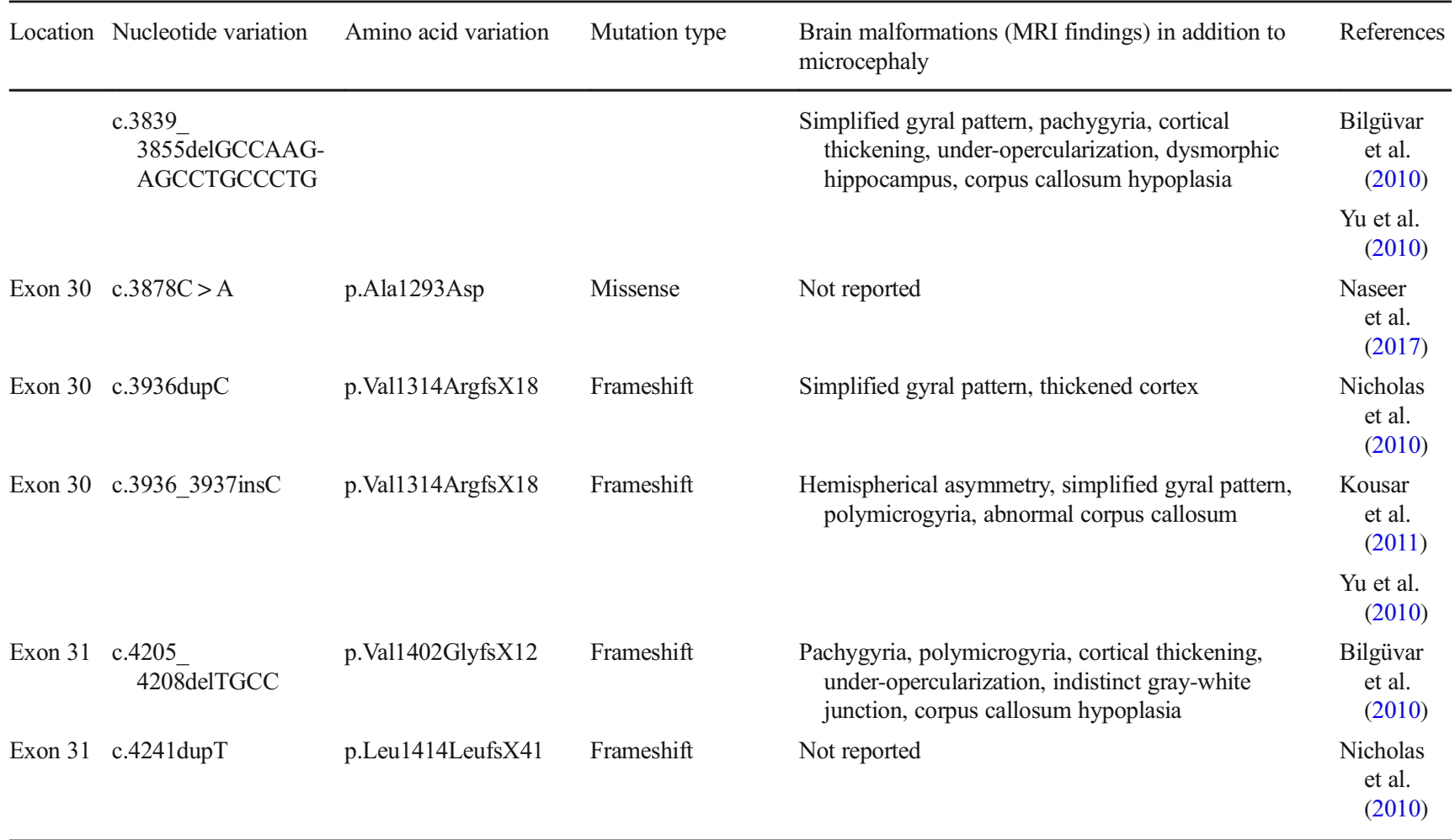

survivin, and borealin (van der Waal et al. 2012). The chromosomal passenger complex associates with the inner centromere until metaphase and then transfers to the spindle midzone, equatorial cell cortex, and midbody in late mitosis and cytokinesis. Aurora B functions include regulation of chromosome interactions with microtubules, chromatid cohesion, spindle stability, and cytokinesis (Carmena et al. 2009).

Brain size at birth is primarily dependent on the ability of neuroprogenitor cells to proliferate and self-renew. While symmetrical division of a neuroprogenitor cell results in the generation of two identical neuroprogenitor cells (thereby increasing the progenitor pool), asymmetrical division leads to the production of one progenitor cell (thereby maintaining the progenitor pool) and a committed precursor, which eventually undergoes migration and differentiates into neuron (Barbelanne and Tsang 2014). In vivo experiments on mice with knockdown or genetic inactivation of Wdr62 and in vitro tests on cells with WDR62/ Wdr62 mutations led to significant progress in the understanding the pathogenesis of microcephaly in patients with WDR62 mutations (Bogoyevitch et al. 2012; Chen et al. 2014; Jayaraman et al. 2016; Sgourdou et al. 2017). Impaired proliferation of neural progenitors and reduced brain size were

Table 2 Compound heterozygous WDR62 mutations and associated brain malformation patterns

\begin{tabular}{|c|c|c|c|c|c|}
\hline Location & $\begin{array}{l}\text { Nucleotide } \\
\text { variation }\end{array}$ & Amino acid variation & Mutation type & $\begin{array}{l}\text { Brain malformations (MRI findings) } \\
\text { in addition to microcephaly }\end{array}$ & Reference \\
\hline Exon 1 & c. $28 \mathrm{G}>\mathrm{T}$ & p.Ala10Ser & Missense & \multirow{2}{*}{$\begin{array}{l}\text { Abnormal gyral pattern (dysgyria), } \\
\text { corpus callosum dysgenesis, } \\
\text { cerebellar atrophy }\end{array}$} & \multirow[t]{2}{*}{ Banerjee et al. (2016) } \\
\hline Exon 2 & c. $189 \mathrm{G}>\mathrm{T}$ & p.Glu63Asp & Missense & & \\
\hline Exon 7 & c. $731 \mathrm{C}>\mathrm{T}$ & p.Ser244Leu & Missense & \multirow[t]{2}{*}{ Not reported } & \multirow[t]{2}{*}{ Miyamoto et al. (2017) } \\
\hline Exon 20 & c. $2413 \mathrm{G}>\mathrm{T}$ & p.Glu805X & Nonsense & & \\
\hline Exon 10 & c. $1313 \mathrm{G}>\mathrm{A}$ & p.Arg438His & Missense & \multirow{2}{*}{$\begin{array}{l}\text { Small frontal lobes, simplified } \\
\text { hippocampal gyration, corpus } \\
\text { callosum hypoplasia, cerebellar } \\
\text { hypoplasia (US only) }\end{array}$} & \multirow[t]{2}{*}{ Farag et al. (2013) } \\
\hline Exon 23 & c.2864_2867delACAG & p.Asp955AlafsX112 & Frameshift & & \\
\hline Exon 17 & c. $2083 \mathrm{delA}$ & p.Ser696AlafsX4 & Frameshift & \multirow{2}{*}{$\begin{array}{l}\text { Polymicrogyria, hemispherical } \\
\text { asymmetry, heterotopia, abnormal } \\
\text { corpus callosum }\end{array}$} & \multirow[t]{2}{*}{ Murdock et al. (2011) } \\
\hline Exon 23 & c. $2472 \_2473 \mathrm{del} A G$ & p.Gln918GlyfsX18 & Frameshift & & \\
\hline
\end{tabular}


observed in these animals (Chen et al. 2014; Jayaraman et al. 2016; Sgourdou et al. 2017). Abnormalities in the centriole duplication, spindle pole orientation, and symmetric/ asymmetric division of neural progenitor cells and defects in the mitotic progression were noticed (Bogoyevitch et al. 2012; Chen et al. 2014; Jayaraman et al. 2016; Sgourdou et al. 2017). Premature delamination of progenitors from the germinal zones and increased apoptosis were also suggested in these experiments as the cause of reduced brain size (Bilgüvar et al. 2010; Bogoyevitch et al. 2012; Chen et al. 2014; Farag et al. 2013; Jayaraman et al. 2016; Nicholas et al. 2010; Sgourdou et al. 2017; Yu et al. 2010). Downregulated Aurora-A-kinase activity was also found in $W d r 62$ mutant mouse embryonic fibroblasts, and investigations on isolated neural progenitor cells suggested that Wdr62 and Aurora A may genetically interact to regulate mitotic progression of neural progenitor cells (Chen et al. 2014).

A recent study revealed more details of the premature depletion of progenitor cells and mitotic progression defects in mice with truncated Wdr62 transcripts (Wdr62 $2^{1-21 / 1-21}$ ) (Sgourdou et al. 2017). Centrosomes with differently aged mother centrioles are differentially inherited by the two daughter cells of asymmetrically dividing radial glia progenitors in the developing neocortex. Whereas the centrosome with the less mature new mother centriole migrates away from the ventricular surface and is largely inherited by differentiating cells, the centrosome with the more mature old mother centriole stays at the ventricular zone surface and is predominantly inherited by renewing radial glia progenitors. WDR62 loss in mutant $W d r 62^{21-21 / 1-21}$ mice disrupted asymmetric centrosome inheritance: the percentage of centrosomes retaining the old mother centriole decreased in the proliferating zones, while the percentage of centrosomes with new mother centrioles increased. The opposite was found in the cortical plate suggesting abnormal migration and possibly differentiation. This disturbed asymmetric centrosome inheritance may lead to premature depletion of progenitor cells from the ventricular zone and microcephaly (Sgourdou et al. 2017). It has also been demonstrated that WDR62 protein can interact with the chromosomal passenger complex. Depletion of any chromosomal passenger complex component disrupts mitotic progression. WDR62 disruption caused a modest decrease in kinetochore levels of Aurora B kinase, and a significant increase in kinetochore levels of survivin in fibroblasts from a patient with homozygous Asp955AlafsX112 mutation in WDR62 suggesting perturbed kinetochore function (Sgourdou et al. 2017). It has also been suggested that the mitotic delay of neural progenitors caused by WDR62 disruption may contribute to the structural abnormalities observed in patients with WDR62 mutations (Sgourdou et al. 2017).

However, human brain disorders can be poorly recapitulated in the mouse. Mice have smooth cerebral cortex that is 1000 times smaller than the abundantly gyrified human cortex. Cortical thinning was found after knockdown or genetic inactivation of Wdr62 in mice (Chen et al. 2014; Jayaraman et al. 2016; Sgourdou et al. 2017) in contrast to thick gray matter and cortical malformations in humans with WDR62 mutations (Tables 1 and 2). This contradiction highlights that loss of Wdr62/WDR62 may elicit divergent brain phenotypes in mice and humans. Recent experiments in Aspm knockdown ferret, a species with a larger, gyrified cortex and greater neural progenitor cell diversity than mice, suggested evolutionarily divergent functions of Aspm in the corticogenesis of mice and ferret (Johnson et al. 2018). Since both microcephaly proteins, Wdr62 and Aspm, define a mother centriole complex regulating centriole biogenesis, apical complex, and cell fate (Jayaraman et al. 2016), similar divergence in Wdr62/WDR62 function can also be hypothesized. Further experiments in ferret might elucidate more details of the abnormal corticogenesis in WDR62 mutations (Johnson et al. 2018).

\section{Conclusions}

Mutations in WDR62 are the second most common cause of autosomal recessive microcephaly. The microcephaly is often associated with pachygyria, cortical thickening, and indistinct gray-white matter border, as in patients in this report; however, a variety of other structural cortical malformations can also occur. Genotype-phenotype correlation cannot be found. Recent investigations highlighted that WDR62 protein plays an essential role in the centrosome function and neural progenitor cell cycle; however, even these elegant experiments failed to explain accurately the genesis of the diverse cortical malformations. Discovery of more aspects of WDR62 function in different animal models may clarify the mechanism of phenotypic heterogeneity.

Acknowledgements The authors thank the patients' parents for their participation in this study.

Authors' contributions $\mathrm{MZ}$ examined the patients and was a major contributor in writing the manuscript; MB and BT interpreted the patients' data; TK, NN, and ZM contributed to gene analysis; OB supervised laboratory work; LSZ analyzed MRI data and designed the study. All authors read and approved the final manuscript.

\section{Compliance with ethical standards}

Conflict of interests The authors declare that they have no conflicts of interest.

Ethical approval and consent to participate The parents of both patients gave written informed consent to enter the study, which was approved by the Ethics Committee of the Faculty of Medicine, University of Szeged (Szeged, Hungary, Reference no: 18/2016-SZTE).

Publisher's note Springer Nature remains neutral with regard to jurisdictional claims in published maps and institutional affiliations. 


\section{References}

Abecasis GR, Cherny SS, Cookson WO, Cardon LR (2002) Merlin-rapid analysis of dense genetic maps using sparse gene flow trees. Nat Genet 30:97-101

Alcantara D, O’Driscoll M (2014) Congenital microcephaly. Am J Med Genet C Semin Med Genet 166C:124-139

Bacino CA, Arriola LA, Wiszniewska J, Bonnen PE (2012) WDR62 missense mutation in a consanguineous family with primary microcephaly. Am J Med Genet A 158A:622-625

Banerjee S, Chen H, Huang H, Wu J, Yang Z, Deng W, Chen D, Deng J, Su Y, Li Y, Wu C, Wang Y, Zeng H, Wang Y, Li X (2016) Novel mutations c.28G $>$ T (p.Ala10Ser) and c.189G $>$ T (p.Glu63Asp) in WDR62 associated with early onset acanthosis and hyperkeratosis in a patient with autosomal recessive microcephaly type 2 . Oncotarget 7:78363-78371

Barbelanne M, Tsang WY (2014) Molecular and cellular basis of autosomal recessive primary microcephaly. Biomed Res Int. https://doi. org/10.1155/2014/547986

Bastaki F, Mohamed M, Nair P, Saif F, Tawfiq N, Aithala G, El-Halik M, Al-Ali M, Hamzeh AR (2016) Novel splice-site mutation in WDR62 revealed by whole-exome sequencing in a Sudanese family with primary microcephaly. Congenit Anom 56:135-137

Bettencourt-Dias M, Hildebrandt F, Pellman D, Woods G, Godinho SA (2011) Centrosomes and cilia in human disease. Trends Genet 27: 307-315

Bhat V, Girimaji SC, Mohan G, Arvinda HR, Singhmar P, Duvvari MR, Kumar A (2011) Mutations in WDR62, encoding a centrosomal and nuclear protein, in Indian primary microcephaly families with cortical malformations. Clin Genet 80:532-540

Bilgüvar K, Öztürk AK, Louvi A, Kwan KY, Choi M, Tatli B, Yalnizoğlu D, Tüysüz B, Çağlayan AO, Gökben S, Kaymakçalan H, Barak T, Bakircioğlu M, Yasuno K, Ho W, Sanders S, Zhu Y, Yilmaz S, Dinçer A, Johnson MH, Bronen RA, Koçer N, Per H, Mane S, Pamir MN, Yalçinkaya C, Kumandaș S, Topçu M, Özmen M, Šestan N, Lifton RP, State MW, Günel M (2010) Whole-exome sequencing identifies recessive WDR62 mutations in severe brain malformations. Nature 467:207-210

Bogoyevitch MA, Yeap YYC, Qu Z, Ngoei KR, Yip YY, Zhao TT, Heng JI, Ng DCH (2012) WD40-repeat protein 62 is a JNKphosphorylated spindle pole protein required for spindle maintenance and timely mitotic progression. J Cell Sci 125:5096-50109

Carmena M, Ruchaud S, Earnshaw WC (2009) Making the Auroras glow: regulation of Aurora A and B kinase function by interacting proteins. Curr Opin Cell Biol 21:796-805

Chang CC, Chow CC, Tellier LC, Vattikuti S, Purcell SM, Lee JJ (2015) Second-generation PLINK: rising to the challenge of larger and richer datasets. Gigascience. https://doi.org/10.1186/s13742-0150047-8

Chen JF, Zhang Y, Wilde J, Hansen K, Lai F, Niswander L (2014) Microcephaly disease gene $W d r 62$ regulates mitotic progression of embryonic neural stem cells and brain size. Nat Commun. https:// doi.org/10.1038/ncomms4885

Farag HG, Froehler S, Oexle K, Ravindran E, Schindler D, Staab T, Huebner A, Kraemer N, Chen W, Kaindl AM (2013) Abnormal centrosome and spindle morphology in a patient with autosomal recessive primary microcephaly type 2 due to compound heterozygous WDR62 gene mutation. Orphanet J Rare Dis. https://doi.org/ $10.1186 / 1750-1172-8-178$

Fujita H, Yoshino Y, Chiba N (2016) Regulation of the centrosome cycle. Mol Cell Oncol. https://doi.org/10.1080/23723556.2015.1075643

Jayaraman D, Kodani A, Gonzalez DM, Mancias JD, Mochida GH, Vagnoni C, Johnson J, Krogan N, Harper JW, Reiter JF, Yu TW, Bae B, Walsh CA (2016) Microcephaly proteins Wdr62 and Aspm define a mother centriole complex regulating centriole biogenesis, apical complex, and cell fate. Neuron 92:813-828

Johnson MB, Sun X, Kodani A, Borges-Monroy R, Girskis KM, Ryu SC, Wang PP, Patel K, Gonzalez DM, Woo YM, Yan Z, Liang B, Smith RS, Chatterjee M, Coman D, Papademetris X, Staib LH, Hyder F, Mandeville JB, Grant PE, Im K, Kwak H, Engelhardt JF, Walsh CA, Bae BI (2018) Aspm knockout ferret reveals an evolutionary mechanism governing cerebral cortical size. Nature 556:370-375

Kodani A, Yu TW, Johnson JR, Jayaraman D, Johnson TL, Al-Gazali L, Sztriha L, Partlow JN, Kim H, Krup AL, Dammermann A, Krogan NJ, Walsh CA, Reiter JF (2015) Centriolar satellites assemble centrosomal microcephaly proteins to recruit CDK2 and promote centriole duplication. elife. https://doi.org/10.7554/eLife.07519

Kousar R, Hassan MJ, Khan B, Basit S, Mahmood S, Mir A, Ahmad W, Ansar M (2011) Mutations in WDR62 gene in Pakistani families with autosomal recessive primary microcephaly. BMC Neurol. https://doi.org/10.1186/1471-2377-11-119

Li D, Roberts R (2001) WD-repeat proteins: structure characteristics, biological function, and their involvement in human diseases. Cell Mol Life Sci 58:2085-2097

Lim NR, Yeap YYC, Ang CS, Williamson NA, Bogoyevitch MA, Quinn LM, Ng DCH (2016) Aurora A phosphorylation of WD40-repeat protein 62 in mitotic spindle regulation. Cell Cycle 15:413-424

McDonell LM, Chardon JW, Schwartzentruber J, Foster D, Beaulieu CL, FORGE Canada Consortium, Majewski J, Bulman DE, Boycott KM (2014) The utility of exome sequencing for genetic diagnosis in a familial microcephaly epilepsy syndrome. BMC Neurol. https:// doi.org/10.1186/1471-2377-14-22

Memon MM, Raza SI, Basit S, Kousar R, Ahmad W, Ansar M (2013) A novel WDR62 mutation causes primary microcephaly in a Pakistani family. Mol Biol Rep 40:591-595

Meraldi P, Lukas J, Fry AM, Bartek J, Nigg EA (1999) Centrosome duplication in mammalian somatic cells requires E2F and Cdk2cyclin A. Nat Cell Biol 1:88-93

Miyamoto T, Akutsu SN, Fukumitsu A, Morino H, Masatsuna Y, Hosoba K, Kawakami H, Yamamoto T, Shimizu K, Ohashi H, Matsuura S (2017) PLK1-mediated phosphorylation of WDR62/MCPH2 ensures proper mitotic spindle orientation. Hum Mol Genet 26:44294440

Murdock DR, Clark GD, Bainbridge MN, Newsham I, Wu YQ, Muzny DM, Cheung SW, Gibbs RA, Ramocki MB (2011) Whole-exome sequencing identifies compound heterozygous mutations in WDR62 in siblings with recurrent polymicrogyria. Am J Med Genet A 155A: 2071-2077

Najmabadi H, Hu H, Garshasbi M, Zemojtel T, Abedini SS, Chen W, Hosseini M, Behjati F, Haas S, Jamali P, Zecha A, Mohseni M, Püttmann L, Vahid LN, Jensen C, Moheb LA, Bienek M, Larti F, Mueller I, Weissmann R, Darvish H, Wrogemann K, Hadavi V, Lipkowitz B, Esmaeeli-Nieh S, Wieczorek D, Kariminejad R, Firouzabadi SG, Cohen M, Fattahi Z, Rost I, Mojahedi F, Hertzberg C, Dehghan A, Rajab A, Banavandi MJS, Hoffer J, Falah M, Musante L, Kalscheuer V, Ullmann R, Kuss AW, Tzschach A, Kahrizi K, Ropers HH (2011) Deep sequencing reveals 50 novel genes for recessive cognitive disorders. Nature 478:57-63

Nardello R, Fontana A, Antona V, Beninati A, Mangano GD, Stallone MC, Mangano S (2018) A novel mutation of WDR62 gene associated with severe phenotype including infantile spasm, microcephaly, and intellectual disability. Brain and Development 40:58-64

Naseer MI, Rasool M, Sogaty S, Chaudhary RA, Mansour HM, Chaudhary AG, Abuzenadah AM, Al-Qahtani H (2017) A novel WDR62 mutation cause primary microcephaly in a large consanguineous Saudi family. Ann Saudi Med 37:148-153

Nicholas AK, Khurshid M, Désir J, Carvalho OP, Cox JJ, Thornton G, Kausar R, Ansar M, Ahmad W, Verloes A, Passemard S, Misson JP, Lindsay S, Gergely F, Dobyns WB, Roberts E, Abramowicz M, 
Woods CG (2010) WDR62 is associated with the spindle pole and is mutated in human microcephaly. Nat Genet 42:1010-1014

Poulton CJ, Schot R, Seufert K, Lequin MH, Accogli A, D'Annunzio G, Villard L, Philip N, de Coo R, Catsman-Berrevoets C, Grasshoff U, Kattentidt-Mouravieva A, Calf H, de Vreugt-Gronloh E, van Unen L, Verheijen FW, Galjart N, Morris-Rosendahl DJ, Mancini GMS (2014) Severe presentation of WDR62 mutation: is there a role for modifying genetic factors? Am J Med Genet Part A 164A:21612171

Prosser SL, Pelletier L (2017) Mitotic spindle assembly in animal cells: a fine balancing act. Nat Rev Mol Cell Biol 18:187-201

Rupp V, Rauf S, Naveed I, Windpassinger C, Mir A (2014) A novel single base pair duplication in WDR62 causes primary microcephaly. BMC Med Genet. https://doi.org/10.1186/s12881-014-0107-4

Sajid Hussain M, Marriam Bakhtiar S, Farooq M, Anjum I, Janzen E, Reza Toliat M, Eiberg H, Kjaer KW, Tommerup N, Noegel AA, Nürnberg P, Baig SM, Hansen L (2013) Genetic heterogeneity in Pakistani microcephaly families. Clin Genet 83:446-451

Sgourdou P, Mishra-Gorur K, Saotome I, Henagariu O, Tuysuz B, Campos C, Ishigame K, Giannikou K, Quon JL, Sestan N, Caglayan AO, Gunel M, Louvi A (2017) Disruptions in asymmetric centrosome inheritance and WDR62-Aurora kinase B interactions in primary microcephaly. Sci Rep. https://doi.org/10.1038/srep43708
Thiele H, Nürnberg P (2005) HaploPainter: a tool for drawing pedigrees with complex haplotypes. Bioinformatics 21:1730-1732

van der Waal MS, Hengeveld RCC, van der Horst A, Lens SMA (2012) Cell division control by the chromosomal passenger complex. Exp Cell Res 318:1407-1420

Wang X, Tsai JW, Imai JH, Lian WN, Vallee EB, Shi SH (2009) Asymmetric centrosome inheritance maintains neural progenitors in the neocortex. Nature 461:947-955

Wang R, Khan A, Han S, Zhang X (2017) Molecular analysis of 23 Pakistani families with autosomal recessive primary microcephaly using targeted next-generation sequencing. J Hum Genet 62:299304

Yu TW, Mochida GH, Tischfield DJ, Sgaier SK, Flores-Sarnat L, Sergi CM, Topçu M, McDonald MT, Barry BJ, Felie J, Sunu C, Dobyns WB, Folkerth RD, Barkovich AJ, Walsh CA (2010) Mutations in WDR62 encoding a centrosome-associated protein, cause microcephaly with simplified gyri and abnormal cortical architecture. Nat Genet 42:1015-1020

Zaqout S, Morris-Rosendahl D, Kaindl AM (2017) Autosomal recessive primary microcephaly $(\mathrm{MCPH})$ : an update. Neuropediatrics 48 : $135-142$ 